\title{
Experimental and numerical analyses on the capacity and the control management of a large flood retention basin situated at the Inn River in Tyrol
}

\author{
Adrian Lindermuth ${ }^{1,{ }^{*}, \text { Bernhard Gems }}{ }^{1}$, Irina Kampel $^{2}$, Christoph Waldhör ${ }^{2}$, Stefan Walder ${ }^{2}$ \\ and Markus Aufleger ${ }^{1}$ \\ ${ }^{1}$ Unit of Hydraulic Engineering, University of Innsbruck, 6020 Innsbruck, Austria \\ ${ }^{2}$ Department of Water Management, Office of the Tyrolean Regional Government, 6020 Innsbruck, \\ Austria
}

\begin{abstract}
The consideration of recent extreme events in flood statistics implies an increase of design flood peaks and discharge loads. With the focus on the $75 \mathrm{~km}$ long Tyrolean Inn River reach downstream the regional capital city Innsbruck, the harmonization of the 100-year flood peak and comprehensive 2d-hydrodynamic modelling simulations indicate the need for an extension of the existing flood protection measures. Lateral protection and object protection measures represent the only feasible option due to the confined areal conditions. However, an increase of the channel capacities would worsen the situation for downstream areas demonstrably. In order to counter this impact, it is planned to build several large controlled flood retention basins situated along the Inn River at the valley floor between Innsbruck and the border to Germany. The retention basin "Voldöpp" as one of these flood polders features a maximum capacity of 1.7 million $\mathrm{m}^{3}$ and a maximum design water depth of $3.6 \mathrm{~m}$. According to current planning the inlet structure consists of four uniform weir fields with two gates each. Aims of the presented experimental and numerical analyses are the investigation of the flow characteristics in close range of the inlet structure, the weir capacity and a possible weir control management. Hydraulic model tests are accomplished at the scale 1:35 according Froude similarity and numerical modelling is done with the software FLOW-3D. Preliminary modelling results confirmed the functionality of the inlet structure and pointed out the need of further tests concerning the potential impacts of intense sediment transport and woody debris.
\end{abstract}

\section{Introduction}

Between the 20th and 23rd of August 2005 a pronounced depression across the Gulf of Genoa, Italy, led to large amounts of precipitation in the Alps. In the western federal provinces of Austria rainfall intensities of more than $20 \mathrm{~mm} / \mathrm{h}$ and accumulated amounts of

*Corresponding author: adrian.lindermuth@uibk.ac.at 
around $280 \mathrm{~mm}$ within 48 hours were registered [1]. On these days, the Tyrolean Inn reached a flood peak in the area of the capital city Innsbruck corresponding to a 200 -year flood event and caused damages in Tyrol totaling 350 million euros. A considerable proportion of these massive flood damages occurred in the tributary rivers, mainly affecting the valley floors of the Rosanna and Trisanna River [1].

The consideration of recent extreme events in flood statistics implies a change of the characteristics of design floods such as the increase of the 100-year flood peak. Potential consequences at design flood conditions are an enlargement of flooded areas, causing increasing affected settlement areas, infrastructure and traffic facilities.

The harmonization of the 100-year flood peak combined with results of 2d-hydrodynamic modelling simulations indicate the need for extensive construction measures along the $75 \mathrm{~km}$ long Tyrolean Inn River downstream the regional capital city Innsbruck in order to protect the vulnerable settlements and industrial areas situated in the vicinity of the river. Lateral protection measures and object protection represent the only feasible options in the confined areal conditions. However, the increase of the channel capacity respectively the elimination of natural flood retention areas along the Inn River in the Lower Inn Valley would worsen the situation for downstream areas demonstrably. In order to account for this impact, several large retention basins along the river with individual capacities of up to 5.4 million cubic meters and specific requirements with regard to the operation management are planned within this major flood protection project [2].

\section{Controlled flood retention basins}

The theoretical concept of controlled retention at major rivers is based on the targeted flooding of areas in the proximity of the endangered areas in order to achieve an optimal, horizontal cutting of the flood hydrograph [3,4]. Due to their low storage capacity, decentralized retention measures such as flood retention basins in the upper reaches of rivers only have a very local influence on the reduction of flood peak discharges. Their retention impact on the downstream major river is greatly restricted by divergent runoff generation in the sub-catchment areas, which results is a temporally varying superposition of single flood peaks $[5,6]$. By contrast, reservoirs for hydropower plants contribute significantly to flood control due to their large storage volume. Annual reservoirs have the potential to retain even large events with return periods of 100 years $[7,8]$. Focusing on the situation at large rivers, controlled flood retention basins situated outside the river represent a possibility to optimize the use of existing flooded areas for retention purposes [9]. Retention measures in-line a major river, e.g. lowered storage rooms of run-off river power plants, are normally insufficient, because the volume to be compensated increases with the increasing discharge and length of the water course [10].

The optimum use of a controlled flood retention basin depends on the most accurate forecast of the flood wave as well as on the successful control of the hydraulic structure. Therefore a supra-regional flood forecast for the entire catchment area, as well as a detailed control strategy of the weir at the intake to the reservoir are required. The retention basin is bounded by a dam respectively the flank of the valley, including an inlet and an outlet structure. During the flood control design event the gates of the inlet structure are opened and thus the retention area is flooded. Optimal use of the retention area is achieved, if the available retention volume can be fully used and, correspondingly the peak discharge as well as the volume of overbanking water in the downstream river reach is minimized over the entire flood event [9]. During or after the respective flood event, the retained volume of water is drained to the receiving water via the outlet structure. In order to prevent a dam failure, a spillway is used to safely manage extreme events, whereas a prescribed freeboard should not be exceeded [3]. The effectiveness of the retention basin can be reduced if the forecast does not correspond to 
the actual flood wave or if the desired control strategies cannot be maintained, e.g. after a failure of a gate.

\section{Project area - Lower Inn Valley downstream of the Ziller tributary}

The national implementation of the European Flood Directive (2007) provides flood protection of settlement area and major economic- and infrastructure facilities up to the 100year design event. In the Tyrolean Lower Inn Valley downstream of the Ziller tributary between the villages Brixlegg and Angath settlement and industrial areas with a total size of approximately 1200 ha, including more than 160 ha of building land, are affected by flooding in case of the flood control design event.

In the Inn Valley downstream of the Ziller tributary between the villages Brixlegg and Angath lateral protection measures with a total length of about $18 \mathrm{~km}$ are required for protection. The cut off inundation areas have to be compensated through optimized controlled retention basins in order to avoid deterioration for the downstream reach. On the basis of previous investigations of variants, a solution with three retention basins featuring a total storage volume of around 8.4 million $\mathrm{m}^{3}$ along the river reach downstream of the Ziller tributary was found. The flood hydrograph, with a peak of $2340 \mathrm{~m}^{3} / \mathrm{s}$ at the upper boundary of this section of the reach is reduced to a peak of about $2060 \mathrm{~m}^{3} / \mathrm{s}$ by activating the retention basins "Voldöpp" and "Radfeld-Kundl" (see Fig. 1), which are situated in close proximity to each other, synchronously at 40-year flood peak conditions.

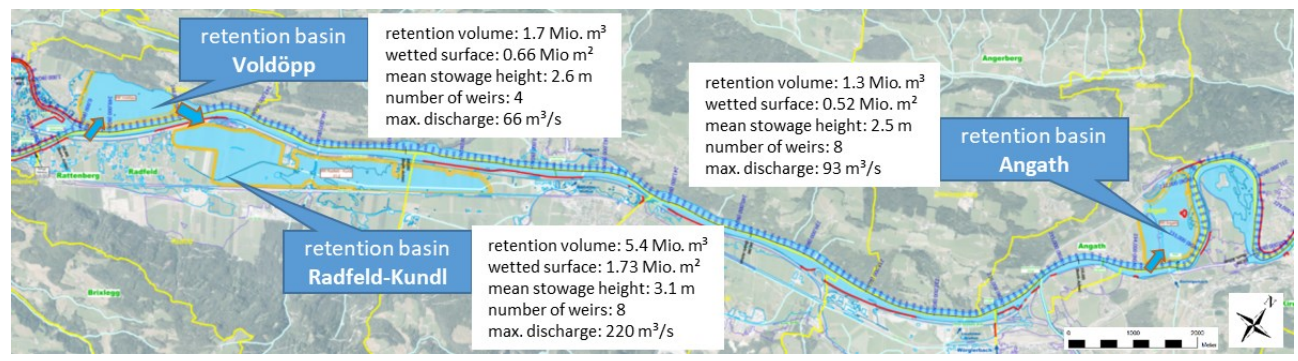

Fig. 1. Project area at the Inn River downstream of the Ziller tributary, covering three planned retention basins in Voldöpp, Radfeld-Kundl and Angath [2, adapted]

The tributaries which enter the Inn River downstream of the two retention basins significantly increase the peak discharge again to $2460 \mathrm{~m}^{3} / \mathrm{s}$. Further downstream, the retention basin "Angath" (see Fig. 1) has the potential to store a volume of 1.3 million $\mathrm{m}^{3}$, which is theoretically sufficient to reduce the peak discharge to $2365 \mathrm{~m}^{3} / \mathrm{s}$. At the control point, the discharge gauge in Kufstein close to the border to Germany, the flood peak amounts to $2384 \mathrm{~m}^{3} / \mathrm{s}$, which equals the status quo [2].

It is focused on the retention basin "Voldöpp" in order to investigate the flow behavior at the inlet structure, to provide hydraulic data for the operation management and to optimize the design of the inlet structure. The retention basin "Voldöpp" (Fig. 2) features a maximum capacity of 1.7 million $\mathrm{m}^{3}$ and leads to a $66 \mathrm{~m}^{3} / \mathrm{s}$ reduction of the peak discharge downstream [2]. The extent of the area investigated, which has a size of 16.8 ha, is shown in Fig. 2. 


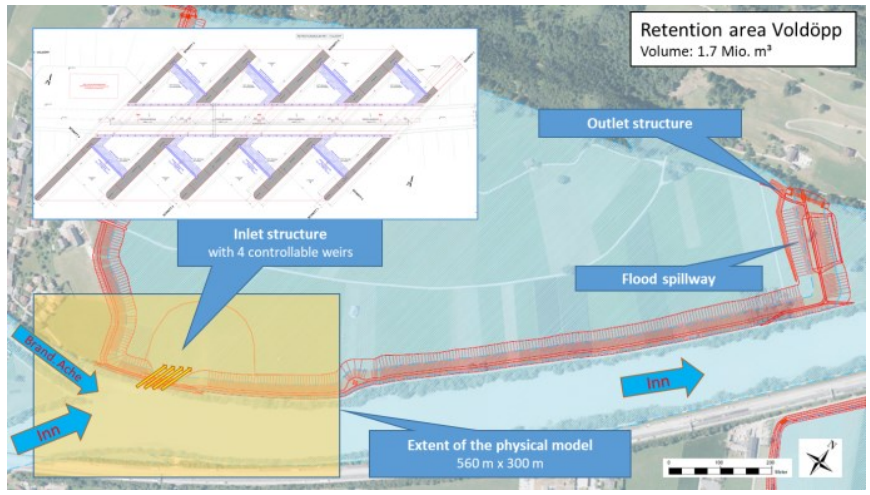

Fig. 2. Retention basin Voldöpp with dams facing the settlement areas and the Inn River, with inlet structure, flood spillway and outlet structure; extent of the physical scale model (1:35) [2, adapted]

Additionally to the Inn River, its tributary on the orographically left side, just upstream of the inlet of the retention basin had to be considered. The so called Brandenberger Ache River contributes a $21 \mathrm{~m}^{3} / \mathrm{s}$ peak discharge during 100-year design flood conditions at the Inn River.

\section{Methodology}

A hydraulic model in the model scale of 1:35 according Froude similarity is reproduced in the hydraulic engineering laboratory. The physical model is based on a digital terrain model, which has been extended by the planned measures. Individual polystyrene elements were formed and joined together to represent the bank areas and the surrounding landscape. Subsequently, a solid channel bottom was installed by a concrete layer, which was shaped with PVC profiles.

The inflow is controlled via several pipes, which are controlled by flaps and inductive flow meters. An inlet basin is located at the upper edge of the model and ensures calm inflow conditions. At the lower edge of the model, the downstream boundary condition can be set via an adjustable flap according to a defined stage-discharge-relation. The runoff through the inlet structure into the retention space is captured at the model boundary and determined by using a Poncelet weir. Five stationary as well as mobile ultrasound devices are installed to measure and monitor the water levels through the entire model extent and specifically in close vicinity to the inlet structure. Fig. 3 shows an overview of the physical scale model and, in more detail, the inlet structure into the retention basin "Voldöpp".

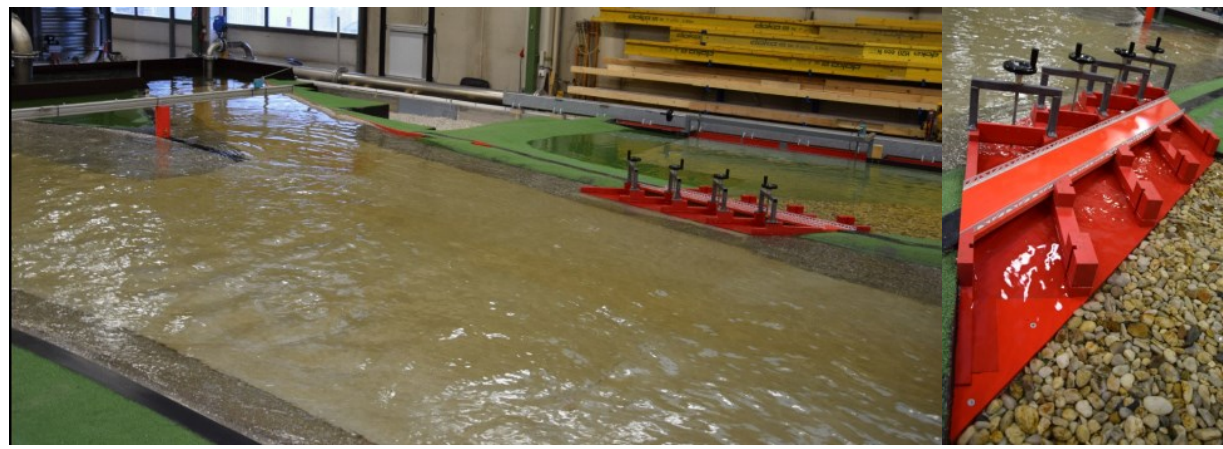

Fig. 3. Physical scale model (1:35) covering the confluence area of the Inn River and the Brandenberger Ache River and the inlet structure of the retention basin Voldöpp, which consists of four controllable weir fields 
Additionally 3d-numerical simulations are carried out on full scale. Thereby detailed information on the flow and velocity conditions in close vicinity of the structure can be provided. The results can be used for the preliminary studies on different plan designs, for the simulation of various hydraulic conditions and, in general, to complement experimental analyses.

3d-numerical modelling is accomplished with the software Flow-3D [11]. For the spatial discretization, a mesh conforming to the structure is used in the area of the inlet structure with a uniform cell size of $0.1 \mathrm{~m}$ and an un-conformed rectangular mesh ( $\mathrm{w} \times 1 \times \mathrm{h}=2 \times 2 \times$ $0.5[\mathrm{~m}])$ for the remaining computational domain. In order to reduce the size ratio between these two mesh elements, a transition area with a cell size of $0.5 \mathrm{~m}$ is implemented. Using the k- $\varepsilon$ model, consisting of two partial differential equations, the turbulence of the viscous fluid is described in the simulation. In order to create as natural flow conditions as possible in the area of the retention structure, the simulation region upstream of the intake structure was chosen slightly larger than the physical model. The downstream model boundary condition is set in accordance with the stage-discharge-relation at the downstream boundary of the physical model. The discharges in the weir fields are recorded by flux surfaces. Additional software tools such as the history probes allow the selective evaluation of flow depths and flow velocities over the simulation process.

The preliminary investigations concerned the analysis of the function of the planned inlet structure. In particular the maximum required discharge into the retention basin depending on the water level in the Inn River and in the retention basin has to be confirmed in advance to any further hydraulic analysis. In further investigations, exceptional load cases such as a 300-year design event, bedload input and driftwood with the associated blocking of the inlet structure are assessed. On the basis of the results obtained, the building is optimized as required. Once this part of the investigation is completed, a series of experiments will be carried out which will result in a set of curves describing the discharge-relationships, depending on the flood discharge in the Inn River. In the course of this process, it is worked out whether the four weir fields are to be operated simultaneously or in a special sequence. Further experiments will be performed to simulate a change of the bed level in the vicinity of the structure and the related effects on the discharge function. These investigations are based on detailed 2D numerical bedload transport modelling [12]. The results, shown in Fig. 3 , demonstrate the changes in the bed level to be expected in the area of the planned structure during the design flood event.
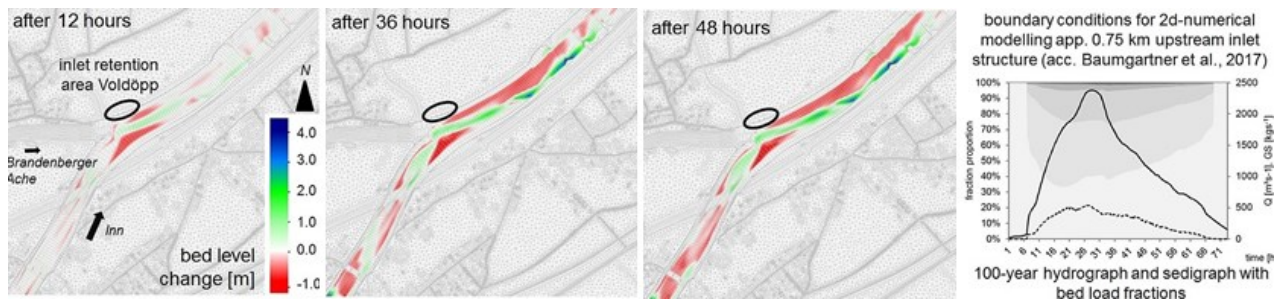

Fig. 4. Bed level changes in the vicinity of the planned inlet structure during the design flood event [acc. 12]

\section{First Results}

Within the first experiments not only the flow conditions and discharge capacity of the inlet structure, but also its controllability was tested. Fig. 5-7 show the corresponding results. The curves illustrate the cumulated flow rate of 4 weir fields depending on the opening width, 
according to the physical model tests and the numerical simulations. In order to compare the results, the values from the physical model were transferred to full scale dimensions according Froude similarity. The results are in good agreement. Fig. 4 additionally includes the total outflows for one or three fully opened gates.

As the diagram in Fig. 5 shows the inlet structure achieves the planned discharge capacity of $66 \mathrm{~m}^{3} / \mathrm{s}$ at 100-year flood peak conditions, even if one weir field fails. It also shows that the free discharge capacity of one weir field approximately equals the discharge capacity of four, partly (for $0.25 \mathrm{~m}$ ) opened gates, which is an important finding with regard to the weir control strategy.

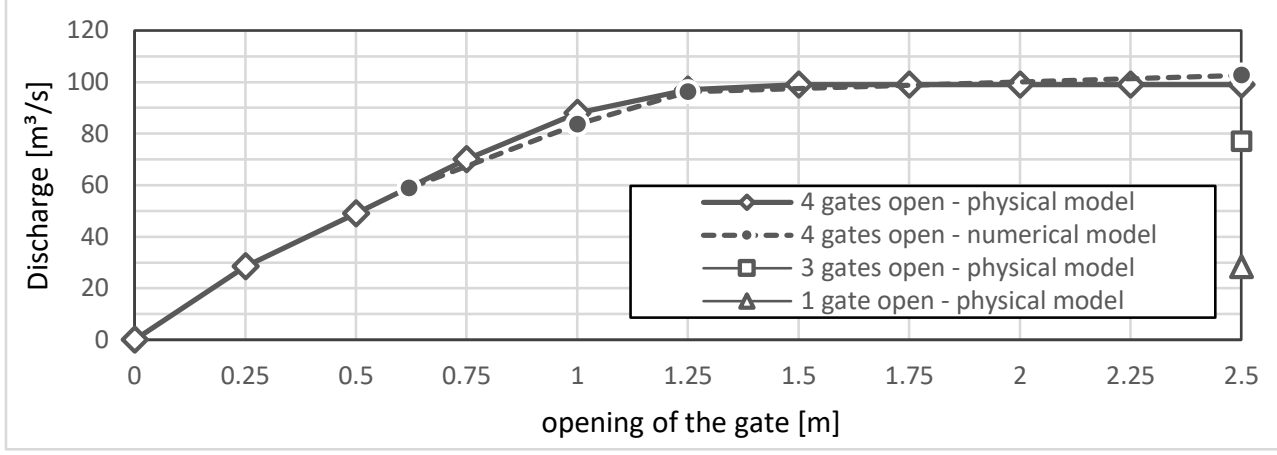

Fig. 5. Results of the physical and the numerical model: Discharge capacity depending on the number of open gates and their opening degree at steady state 100-year design flood peak conditions and for an empty retention basin

In order to analyze the influence of a failure of single weir fields on the discharge behavior, investigations were carried out with 3 opened gates. Different combinations were tested. The diagram in Fig. 6 shows the results for both, an empty and filled retention basin, whereas the points indicate the discharge, given on the left ordinate and the bars represent the reduction of the discharge depending on the water level in the reservoir.

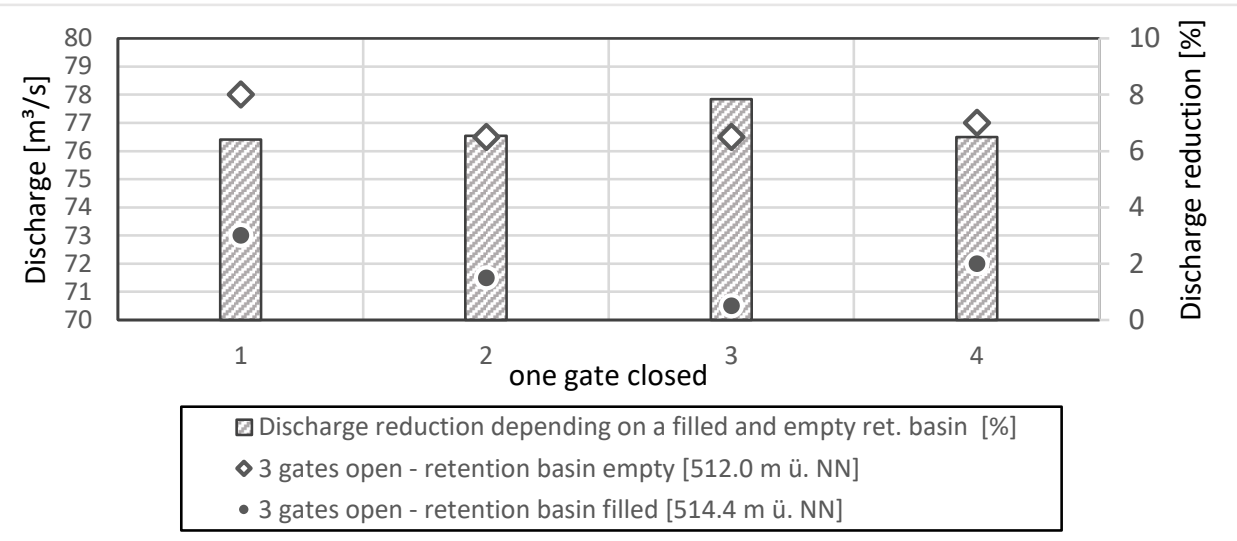

Fig. 6. Discharge investigations with one of four weir fields closed in the case of an empty and filled retention basin

Subsequently experiments were carried out with only one opened gate. The results are presented in Fig. 7. Due to an increase of the water level in the retention basin, the discharge capacity decreases by $4.8 \%$ on average. In comparison, a mean reduction of $6.8 \%$ was achieved in the studies with 3 opened gates. It could be identified, that weir field number 3 has the largest and number 1 the lowest discharge capacity. 

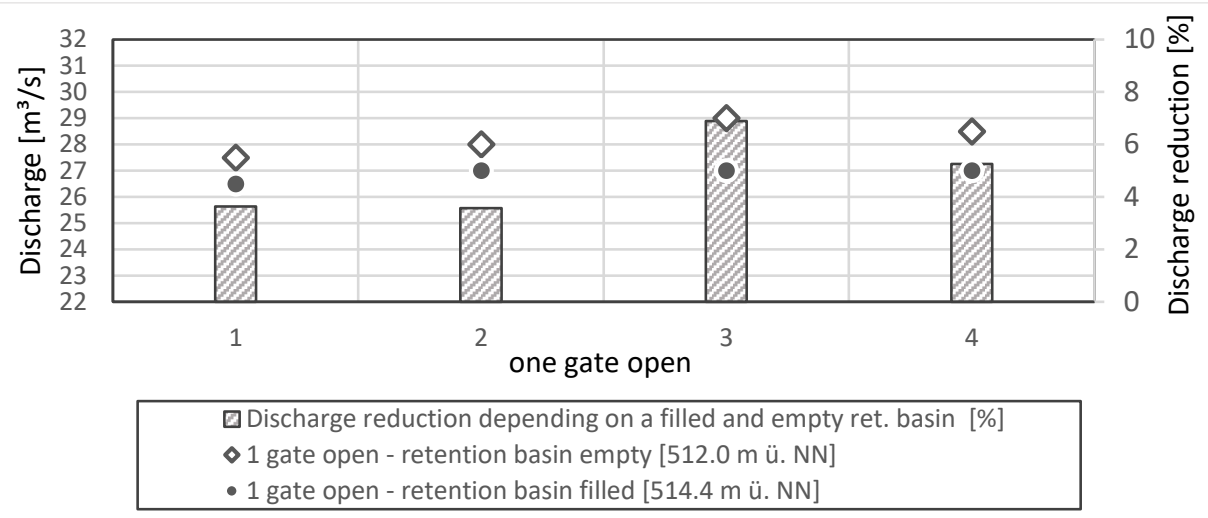

Fig. 7. Discharge investigations with one of four weir fields opened in the case of an empty and filled retention basin

Contour plots of the numerical simulations illustrate that the main stream of the Inn River is not in the vicinity of the intake structure. The discharge capacity therefore appears to be independent of the surrounding flow velocity. Fig. 8 shows the situation during the 100 -year control flood peak. The four weir fields are completely open and the retention basin is assumed to be empty.

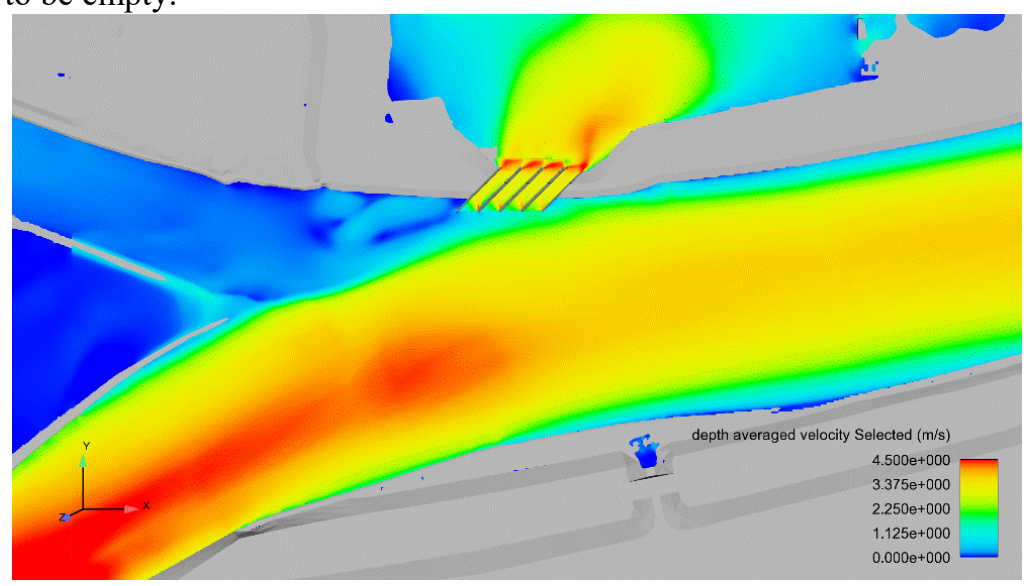

Fig. 8. Depth-averaged velocity in close vicinity to the inlet structure during a 100 -year design flood peak and with an open inlet structure

\section{Summary}

Controlled retention basins in the bypass are designed to allow a controlled reduction of the peak discharge from occurring flood events. Important requirements for a successful use respectively a sound flooding of the available retention volume are a targeted weir control strategy in accordance with a flood prediction model.

For the development of a control strategy of the planned retention basin "Voldöpp" in the Lower Inn Valley, a numerical and a physical model reproducing the inlet structure and the hydraulically relevant main river and retention basin are accomplished. Results of the preliminary investigation show that the required flow capacity and controllability can be achieved by the original design of the structure. 
Influences caused by bedload and driftwood are determined in the following investigations and if necessary the design of the intake structure will be optimized. Subsequently, experiments are carried out with different flood peaks in the receiving water and various water levels in the retention basin in order to provide all relevant data for the future operational management of the retention basin.

\section{References}

1. R. Godina, P. Lalk, P. Lorenz, G. Müller, and V. Weilguni: Hochwasser 2005 Ereignisdokumentation, Teilbericht des Hydrographischen Dienstes; Federal Ministry of Sustainability and Tourism (BMNT) Austria, Vienna (2006).

2. ARGE DonauConsult Ingenieurbüro GmbH, and ILF-Consulting Engineers: Hochwasserschutz Unteres Unterinntal - Zusammenfassender Bericht und Detailpläne, Project Report on behalf of the Office of the Tyrolean Regional Government (unpublished). (2016).

3. C. Patterson, T. Rosenberg, and Warren, A.: Design, operation and adaptation of reservoirs for flood storage. Environment Agency, Deanery Road, Bristol, United Kingdom (2016).

4. J. Plank, and C. Leeb: Der gesteuerte Flutpolder Riedensheim. In: Wasserbau-Mehr als Bauen im Wasser, 18. Gemeinschafts-Symposium der Wasserbau-Institute TU München, TU Graz und ETH Zürich. pp. 155-166. Hydraulic and Water Resources Engineering, Technical University of Munich, Wallgau, Upper Bavaria (2016).

5. S. Haider: Retention in unseren Flüssen: Prozessbeschreibung und aktuelle Fragen. Österr. Wasser- Abfallwirtsch. 66, pp. 59-66 (2014).

6. D. Skublics, and S. Seibert: Flussgebietsweite operationelle Steuerung der Abflüsse im Extrembereich - Projekt für das Landesamt für Umwelt LfU-Bayern (unpublished). Lehrstuhl und Versuchsanstalt für Wasserbau und Wasserwirtschaft (2010).

7. R. Boes, S. Perzlmaier, H. Schönlaub, M. Linser, and B. Hofer: Flood retention by storage reservoirs and alpine water intakes. Presented at the 76. ICOLD Annual Meeting 2008 , Sofia June 2 (2008).

8. F. Schöberl: Hochwasserschutz durch Hochwasserrückhalt. Innsbrucker Ber. 2003-07. (2003).

9. M. Fischer: Ungesteuerte und gesteuerte Retention entlang von Fließgewässern: Beurteilung der Wirksamkeit möglicher Maßnahmen unter Verwendung hydrodynamisch-numerischer Modellierung. Hydraulic and Water Resources Engineering, Technical University of Munich, Münchn (2008).

10. E. Lüke, D.F. Vetsch, M. Gerber, and R. Boes: Wehrregulierung zur Dämpfung des Hochwasserscheitels am Beispiel der Wehranlage Langkampfen am Inn. In: WasserbauMehr als Bauen im Wasser, 18. Gemeinschafts-Symposium der Wasserbau-Institute TU München, TU Graz und ETH Zürich. pp. 167-176. Hydraulic and Water Resources Engineering, Technical University of Munich, Wallgau, Upper Bavaria (2016).

11. Flow Science, Inc.: Flow3D - User Manual - v11.2 Documentation. (2016).

12. K. Baumgartner, B. Gems, S. Walder, F. Auer, M. Federspiel, and M. Aufleger: Influence of bed-load transport on the design offlood protection and retention measures in gravel-bad rivers - application of HYDRO_FT-2D for the Tyrolean River. In: Proceedings of the 37th IAHR World Congress August 13 - 18, 2017. pp. 608-615. International Association for Hydro-Environment Engineering and Research (IAHR), Kuala Lumpur, Malaysia (2017). 